\title{
PEMANFAATAN “TWITTER TMCPOLDAMETRO" DALAM MEMENUHI KEBUTUHAN INFORMASI PARA PENGGUNA JALAN RAYA
}

\author{
Isni Puspitadewi ${ }^{1}$, Wina Erwina ${ }^{2}$, Nuning Kurniasih ${ }^{3}$ \\ ${ }^{1,2,3}$ Program Studi Ilmu Perpustakaan \\ Universitas Padjadjaran \\ ${ }^{1}$ puspitadewiisni@gmail.com \\ ${ }^{2}$ wina.erwina@gmail.com, ${ }^{3}$ nuning.kurniasih@unpad.ac.id
}

\begin{abstract}
This research is about how the utilization of "twitter TMC Polda Metro" in satisfy information need of the users of the higway. The purpose of this research is to know the extent of utilization of "twitter TMC Polda Metro" in meet information need of the new approach, the approach needs regular information, in-depth information needs approach, and the approach to information needs at a glance the user of the highway. This reaserach method used is descriptive method intended to describe or expose variables that become the object of his research. Technic to collect data done with question form, interviews, and study literature. Population in this research are the follower "twitter TMC Polda Metro" and technic to take sampel used accidental sampling to anyone around Polda Metro. Based on the reaserach results that using "twitter TMC Polda Metro" enough to satisfy new information needs, daily information needs approach, to deep information needs approach, and information needs approach of the users of the higway approach.
\end{abstract}

\section{Keywords: Twitter, information need}

A ABSTRAK - Penelitian ini adalah mengenai bagaimana pemanfaatan "twitter TMCPolda Metro" dalam memenuhi kebutuhan informasi para pengguna jalan raya. Tujuan penelitian ini adalah untuk mengetahui sejauh mana pemanfaatan "twitter TMCPoldaMetro" dalam memenuhi pendekatan kebutuhan informasi mutkahir, pendekatan kebutuhan informasi rutin, pendekatan kebutuhan informasi mendalam, dan pendekatan kebutuhan informasi sekilas para pengguna jalan raya. Metode penelitian yang digunakan adalah metode deskriptif yang dimaksudkan untuk menggambarkan atau memaparkan variabel-variabel yang menjadi objek penelitiannya. Teknik pengambilan datanya dilakukan melalui angket, wawancara, dan studi pustaka. Adapun yang menjadi populasi dalam penelitian ini adalah follower "twitter TMCPoldaMetro" dan teknik pengambilan sampelnya menggunakan teknik accidental sampling yaitu mengambil sampel siapa saja yang ada atau yang kebetulan ditemui. Berdasarkan hasil penelitian dapat diketahui bahwa dengan memanfaatkan "twitter TMCPoldaMetro" cukup memenuhi pendekatan kebutuhan informasi mutakhir, pendekatan kebutuhan informasi rutin, pendekatan kebutuhan informasi mendalam, dan pendekatan kebutuhan informasi sekilas para pengguna jalan raya.

Kata Kunci : Twitter, kebutuhan informasi

\section{PENDAHULUAN}

Dalam memasuki era globalisasi seperti sekarang ini, internet sudah menjadi kebutuhan sehari-hari bagi masyarakat. Internet berperan sebagai salah satu wadah dalam dunia teknologi informasi dan komunikasi. Situs jejaring sosial merupakan salah satu fenomena dari perkembangan kemajuan teknologi komunikasi dan informasi, dimana saat ini sedang menjadi topik yang menarik di Indonesia bahkan di dunia. Namun yang saat ini sedang menjadi 'trend' baru yang sedang hangat dibicarakan di kalangan masyarakat Indonesia adalah twitter.

Indonesia menduduki peringkat pertama sebagai pengguna twitter terbanyak di Asia dan menduduki peringkat keenam di dunia dengan 
data sebanyak 2,41\% dari populasi masyarakat Indonesia yang berjumlah 237.556.363 orang yang tercatat sebagai pengguna twitter (Syimen, 2012). Twitter merupakan media sosial yang hadir dengan format yang berbeda, dimana twitter memiliki konsep yaitu menyebarkan informasi pesan secara singkat, padat dan real time dengan kalimat yang kurang dari 140 karakter kepada pembacanya di seluruh dunia yang bisa digunakan sebagai sarana penyebar informasi kepada semua orang baik yang dikenal maupun tidak, untuk memberitahukan keberadaan penggunanya.

Sesuai dengan konsep yang diusungnya, banyak individu, kelompok ataupun lembaga dengan latar belakang yang berbeda-beda menggunakan twitter sebagai media online untuk memberikan informasi yang sedang terjadi. Salah satu lembaga pemberi informasi yang menggunakan layanan media sosial ini adalah "twitter TMCPoldaMetro”.

"twitter TMCPoldaMetro" adalah sebuah akun media sosial yang dibuat oleh Polda Metro Jaya untuk memberikan informasi seputar kondisi jalan raya. Tujuan dari dibuatnya akun ini untuk memberikan informasi kepada para pengguna jalan raya supaya mereka bisa mengetahui kondisi yang terjadi di jalan raya sehingga para pengguna bisa mengantisipasi keadaan sebelum mereka beraktifitas menggunakan jalan raya. Melihat kegunaan dan pemanfaatan serta isi informasi yang diberikan "twitter TMCPoldaMetro" yang dibaur menggunakan tema yang diusung twitter, maka perlu untuk dilakukan penelitian untuk mengetahui sejauh mana dan bagaimana pemanfaatan "twitter TMCPoldaMetro" dalam memenuhi kebutuhan informasi para pengguna jalan raya. Berdasarkan hal itu, maka penulis rumuskan hasil capaian penelitian ini sebagai berikut:

1. Untuk mengetahui pemanfaatan "twitter TMCPoldaMetro" dalam memenuhi kebutuhan informasi mutakhir para pengguna jalan raya

2. Untuk mengetahui pemanfaatan "twitter TMCPoldaMetro" dalam memenuhi kebutuhan informasi rutin para pengguna jalan raya

3. Untuk mengetahui pemanfaatan "twitter TMCPoldaMetro" dalam memenuhi kebutuhan informasi mendalam para pengguna jalan raya

4. Untuk mengetahui pemanfaatan "twitter TMCPoldaMetro" dalam memenuhi kebutuhan informasi sekilas para pengguna jalan raya.

\section{TINJAUAN PUSTAKA}

Menurut Zorkoczy, informasi merupakan suatu pengertian yang diekspresikan melalui ungkapan mengenai suatu kejadian, kenyataan, atau gagasan, dengan menggunakan lambanglambang yang telah diketahui dan disepakati bersama (Zorkoczy, 1988). Sebuah data harus dikemas dan diproses dengan cara- cara tertentu untuk menjadi informasi yang berguna. Sebuah informasi akan dicari jika mengandung unsur yang menarik bagi seseorang, biasanya sebuah pesan di media diberi bumbu-bumbu tambahan 
agar khalayak semakin penasaran dan tertarik untuk menelusuri sebuah informasi.

Pawit M. Yusup dalam bukunya "Pedoman Mencari Informasi”, menyatakan informasi merupakan kumpulan kata, fakta, data, fenomena yang terangkum dalam bungkusan bahasa maupun kata-kata (Yusup, 1995). Dapat disimpulkan informasi memiliki unsur-unsur sebagai berikut :

1. Merupakan suatu data, baik berupa fakta, kejadian, pendapat, keterangan, dan sebagainya yang dikumpulkan atau diperoleh dari sumber yang diamati

2. Data yang diolah, artinya data tersebut telah diproses dan ditafsirkan secara manual atau komputerisasi dan dianalisis, baik secara kuantitatif maupun kualitatif

3. Suatu pesan, berarti mengandung suatu informasi atas bahan tertentu

4. Dikomunikasikan, berarti disampaikan dengan metode tertentu dengan bantuan media tertentu pula kepada pihak lain atau pengguna informasi.

Informasi pada saat ini sudah menjadi kebutuhan. Masyarakat mencari "sesuatu" yang bermanfaat dan memenuhi kebutuhannya. Setiap orang mempunyai kebutuhan yang berbeda dalam kehidupannya, atau teori kebutuhan berangkai. Seperti yang dirumuskan oleh Maslow dalam Handoko teori kebutuhan berangkai, terdiri dari : 1. kebutuhan biologis; 2. kebutuhan akan rasa aman; 3. kebutuhan akan cinta kasih dan rasa memiliki; 4. kebutuhan akan penghargaan; 5. kebutuhan untuk tahu; 6. kebutuhan akan keindahan; 7. kebutuhan akan kebebasan bertindak (aktualisasi diri) (Handoko, 1992).

Kebutuhan menurut Jalaluddin Rakhmat adalah kondisi internal yang memerlukan pemuasan, kebutuhan juga adalah tenaga dasar yang memotivasi tingkah laku manusia. Dalam definisi tersebut dapat disimpulkan bahwa jika kebutuhan tersebut dibangkitkan maka orang terdorong bergerak untuk memenuhi kebutuhan biologis seperti lapar dan dahaga, tetapi juga karena dorongan psikologis seperti rasa ingin tahu, kebutuhan akan kasih sayang, dan keinginan untuk memuja (Rakhmat, 1999).

Kebutuhan akan informasi berubah sejalan dengan pekerjaan pemakai dan perkembangan waktu. Kebutuhan informasi pemakai antara satu dengan yang lainnya berbeda, maka diperlukan sumber informasi yang berbeda pula dalam memenuhi kebutuhan informasi pengguna dapat berorientasi pada masalah yang dihadapinya (Yusup, 1995). Ketika masalah tersebut datang setiap saat, maka pada saat itu pengguna membutuhkan informasi yang sesuai dengan masalahnya.

Ditinjau dari perbedaannya, sesuatu dapat dibedakan berdasarkan pada macamnya, bentuknya, cara penyajiannya, cakupan isi, kemutakhirannya dan lain sebagainya. Menurut Guha, kebutuhan informasi pengguna dapat dilihat melalui beberapa pendekatan (Guha, 1978), yaitu:

1. Pendekatan Kebutuhan Informasi Mutakhir (current need approach)

Pendekatan kebutuhan yang bersifat mutakhir dimana pendekatan kebutuhan 
ini merupakan kebutuhan akan informasi terbaru yang mendorong setiap pengguna informasi untuk selalu aktif untuk mendapatkan informasi yang terbaru. Dengan pendekatan kebutuhan informasi mutakhir ini, setiap pengguna informasi harus selalu berinteraksi dengan sistem informasi untuk bisa mendapatkan informasi yang dibutuhkannya guna meningkatkan pengetahuannya. Pendekatan kebutuhan informasi mutakhir akan memotivasi pengguna untuk setiap saat berinteraksi dengan sistem informasi supaya dapat memenuhi kebutuhan informasi yang terbaru dan teraktual setiap harinya

2. Pendekatan Kebutuhan Informasi Rutin (everday need approach)

Pendekatan kebutuhan informasi rutin bersifat spesifik dan cepat, dimana pendekatan kebutuhan ini menuntut adanya jawaban yang tepat dari pengolahan informasi dalam memenuhi kebutuhan pengguna informasi

3. Pendekatan Kebutuhan Informasi Mendalam (exhaustive need approach)

Pendekatan kebutuhan informasi mendalam mengisyaratkan adanya suatu ketergantungan yang tinggi dari pengguna terhadap informasi yang dibutuhkan. Kebutuhan ini membuat pengguna informasi membutuhkan informasi yang akurat, spesifik dan lengkap
4. Pendekatan Kebutuhan Informasi Sekilas (cathcing up need approach)

Pendekatan kebutuhan informasi yang bersifat sekilas dimana dengan kebutuhan ini berarti seseorang membutuhkan informasi yang sekilas saja tetapi memberikan gambaran lengkap tentang suatu topik. Pendekatan kebutuhan ini membuat pengguna informasi juga membutuhkan informasi yang ringkas dan singkat namun jelas informasinya dan sesuai dengan kebutuhan informasi yang dibutuhkan oleh pengguna.

Malvin Voight mengatakan bahwa seseorang dapat berinteraksi dengan sesuatu sistem informasi dalam cara dan waktu yang berbedabeda, tergantung pada tujuan dari pekerjaannya, tingkatan pekerjaannya, minat umum, banyak informasi yang tersedia untuknya dan seterusnya, berkaitan dengan kebutuhan informasi tersebut maka, dalam hal ini pengguna informasi merupakan orang atau konsumen dari sebuah sistem informasi untuk mencari informasi yang dibutuhkan (Guha, 1978). Informasi yang dicari adalah informasi yang dapat memecahkan masalah-masalah kehidupan, penunjang kegiatannya dan dapat menambah pengetahuannya.

Internet merupakan sebuah jaringan komputer dimana jaringan tersebut saling terhubung dan dapat digunakan untuk keperluan komunikasi dan pencarian informasi. Menurut Laquey, "internet merupakan jaringan longgar dari ribuan jaringan komputer yang menjangkau jutaan orang di seluruh dunia" (Laquey, 1997). 
Internet sudah banyak dimanfaatkan oleh masyarakat, baik untuk kepentingan hiburan, sosial, kebutuhan informasi, atau untuk mengembangkan bisnis. Misi awalnya adalah menyediakan sarana bagi para peneliti untuk mengakses data dari sejumlah sumber daya perangkat keras komputer, yang mahal. Namun, sekarang internet sudah berkembang menjadi ajang komunikasi yang sangat cepat dan efektif, sehingga telah menyimpang jauh dari misi awalnya. Situs jejaring sosial merupakan fenomena dari perkembangan kemajuan teknologi dan informasi yaitu internet. Salah satu situs jejaring sosial yang bisa dimanfaatkan dalam memberikan informasi adalah "twitter".

Twitter merupakan media sosial yang hadir dengan format yang berbeda, dimana twitter memiliki konsep yaitu menyebarkan informasi pesan secara singkat, padat dan real time dengan kalimat yang kurang dari 140 karakter kepada pembacanya di seluruh dunia yang bisa digunakan sebagai sarana penyebar informasi kepada semua orang baik yang dikenal maupun tidak, untuk memberitahukan keberadaan penggunanya. Twitter adalah sebuah situs web yang dimiliki dan dioperasikan oleh Twitter Inc, yang menawarkan jaringan sosial berupa microblog sehingga memungkinkan penggunanya untuk mengirim dan membaca pesan yang disebut kicauan (tweets).

\section{METODE PENELITIAN}

Metode yang digunakan peneliti adalah metode penelitian deskriptif, yaitu penelitian yang melukiskan fakta dan karakteristik populasi secara faktual dan cermat yang bertujuan mengumpulkan informasi yang menjelaskan gejala yang ada, menggambarkan kondisi dan praktek-praktek yang berlaku, dan membuat evaluasi (Rakhmat, Metode Penelitian Komunikasi, 2005). Metode deskriptif dipilih sebagai tehnik penelitian oleh peneliti karena penelitian deskriptif dapat lahir dari kebutuhan seperti halnya permasalahan dalam penelitian ini.

Pada penelitian ini yang menjadi populasi yaitu follower "twitter TMCPoldaMetro". Berdasarkan data yang diperoleh peneliti, jumlah follower "twitter TMCPoldaMetro" adalah 564.046 orang. Data tersebut berdasarkan data dari jumlah follower akun "twitter TMCPoldaMetro” pada tanggal 18 Januari 2012. Dalam menentukan sampel penelitian ini menggunakan accidental sampling. Accidental sampling adalah mengambil sampel siapa saja yang ada atau yang kebetulan ditemui (Rakhmat, Metode Penelitian Komunikasi, 2005). Jumlah sampel dalam penelitian ini adalah 100 orang follower "twitter TMCPoldaMetro".

Adapun teknik pengumpulan data yang digunakan yaitu : (1) Angket, (2) Wawancara, (3) Studi Pustaka. Teknik analisis data yang digunakan adalah analisis deskriptif yang digunakan untuk menganalisis data dengan cara mendeskripsikan atau menggambarkan data yang telah terkumpul sebagaimana adanya tanpa membuat kesimpulan yang berlaku untuk umum atau generalisasi. Dalam penelitian kuantitatif analisis data menggunakan statistik. Interpretasi bertujuan menafsirkan hasil analisis secara lebih luas untuk menarik kesimpulan. 


\section{HASIL DAN PEMBAHASAN}

Hasil dan pembahasan berikut merupakan hasil dari jawaban responden terhadap angket yang disebarkan kepada follower "twitter TMCPoldaMetro". Pemenuhan kebutuhan informasi mutakhir responden sudah cukup terpenuhi berdasarkan penilaian 43 responden yang menilai informasi "twitter TMCPoldaMetro" cukup memenuhi kebutuhan informasi terbaru dan 57 responden yang menilai informasi "twitter TMCPoldaMetro" cukup memotivasi untuk mencari informasi secara aktif. Kondisi ini menggambarkan bahwa secara umum, pemenuhan kebutuhan informasi mutakhir sudah cukup terpenuhi karena informasi yang diberikan "twitter TMCPoldaMetro" cukup memenuhi kebutuhan informasi terbaru para pengguna jalan raya dan cukup memotivasi mereka untuk aktif menggunakan “twitter TMCPoldaMetro" dalam mendapatkan informasi untuk memenuhi kebutuhan informasi mutakhirnya.

Pemenuhan kebutuhan informasi rutin responden sudah cukup terpenuhi berdasarkan penilaian 36 responden yang menilai informasi “twitter TMCPoldaMetro" cukup memenuhi kebutuhan informasi secara rutin dan 42 responden yang menilai informasi "twitter TMCPoldaMetro" cukup memenuhi kebutuhan informasi dengan tepat. Kondisi ini menggambarkan bahwa secara umum, pemenuhan kebutuhan informasi rutin sudah cukup terpenuhi karena informasi yang diberikan "twitter TMCPoldaMetro" cukup memenuhi pemenuhan kebutuhan informasi para pengguna jalan raya secara rutin dan juga cukup memenuhi pemenuhan kebutuhan informasi para pengguna jalan raya dengan tepat.

Pemenuhan kebutuhan informasi mendalam responden sudah cukup terpenuhi berdasarkan penilaian 40 responden yang menilai informasi "twitter TMCPoldaMetro" cukup memenuhi kebutuhan akan informasi yang akurat, 43 responden menilai informasi "twitter TMCPoldaMetro" cukup memenuhi kebutuhan informasi secara spesifik dan 36 responden menilai cukup ketergantungan terhadap informasi yang diberikan "twitter TMCPoldaMetro”. Kondisi ini menggambarkan bahwa secara umum, Pemenuhan kebutuhan informasi mendalam para pengguna jalan raya sudah cukup terpenuhi dilihat berdasarkan informasi "twitter TMCPoldaMetro" yang dimanfaatkan oleh pengguna cukup memenuhi kebutuhan para pengguna jalan raya akan informasi yang akurat, cukup memenuhi kebutuhan informasi secara spesifik dan juga membuat para pengguna jalan raya cukup ketergantungan terhadap informasi yang mereka butuhkan.

Pemenuhan kebutuhan informasi sekilas responden sudah cukup terpenuhi berdasarkan penilaian 36 responden yang menilai informasi “twitter TMCPoldaMetro" cukup memenuhi kebutuhan akan informasi sekilas dan 49 responden yang menilai topik informasi "twitter TMCPoldaMetro" sudah jelas. Kondisi ini menggambarkan bahwa secara umum, Pemenuhan kebutuhan informasi sekilas sudah 
cukup terpenuhi karena informasi yang diberikan “twitter TMCPoldaMetro" cukup memenuhi kebutuhan para pengguna jalan raya akan informasi sekilas dan setiap topik informasi yang diberikan "twitter TMCPoldaMetro" juga sudah jelas sehingga cukup memenuhi kebutuhan informasi sekilas para pengguna jalan raya.

\section{SIMPULAN}

Berikut ini adalah kesimpulan penelitian mengenai "Bagaimana Pemanfaatan "twitter TMCPoldaMetro" dalam Memenuhi Kebutuhan Informasi Para Pengguna Jalan Raya?", diantaranya sebagai berikut:

1. Dengan memanfaatkan "twitter TMCPoldaMetro" maka pemenuhan kebutuhan informasi mutakhir para pengguna jalan raya sudah cukup terpenuhi karena informasi "twitter TMCPoldaMetro” yang dimanfaatkan pengguna cukup memenuhi kebutuhan informasi terbaru para pengguna jalan raya dan cukup memotivasi mereka untuk aktif menggunakan "twitter TMCPoldaMetro" dalam mendapatkan informasi untuk memenuhi kebutuhan informasi mutakhirnya

2. Dengan memanfaatkan "twitter TMCPoldaMetro" maka pemenuhan kebutuhan informasi rutin para pengguna jalan raya sudah cukup terpenuhi karena informasi "twitter TMCPoldaMetro" yang dimanfaatkan oleh pengguna cukup memenuhi pemenuhan kebutuhan informasi para pengguna jalan raya secara rutin dan memenuhi kebutuhan informasi secara spesifik dan juga membuat para pengguna jalan raya cukup ketergantungan terhadap informasi yang mereka butuhkan

3. Dengan memanfaatkan "twitter TMCPoldaMetro" maka pemenuhan kebutuhan informasi sekilas para pengguna jalan raya sudah cukup terpenuhi karena informasi "twitter TMCPoldaMetro" yang dimanfaatkan oleh pengguna cukup memenuhi kebutuhan para pengguna jalan raya akan informasi sekilas dan setiap topik informasi "twitter TMCPoldaMetro" yang dimanfaatkan pengguna juga sudah jelas sehingga cukup memenuhi kebutuhan informasi sekilas para pengguna jalan raya.

\section{DAFTAR PUSTAKA}

Guha. (1978). Documentation and Information. Calcutta: The World Press Private Limited.

Handoko, M. (1992). Motivasi Daya Penggerak Tingkah Laku. Yogyakarta: Kanisius.

Laquey, T. (1997). Sahabat Internet Pedoman bagi Pemula untuk Memasuki Jaringan Global. Bandung: Penerbit ITB.

Rakhmat, J. (1999). Psikologi Komunikasi. Bandung: Remaja Rosdakarya Offset.

Rakhmat, J. (2005). Metode Penelitian Komunikasi. Bandung: Remaja Rosdakarya.

Syimen. (2012). Pengertian twitter. Retrieved March 2012, from Pengertian twitter: http://www.syimen.com/twitter/pengertian - twitter 
Yusup, P. M. (1995). Pedoman Praktis Mencari

Informasi. Bandung: Remaja Rosdakarya.

Zorkoczy, P. (1988). Teknologi Informasi.

Jakarta: Elex Media Komputindo. 